\title{
Detection of sugarcane leaf scald from latent infections
}

\section{Detecção da escaldadura da cana de açúcar em infeções latentes}

\author{
Vanessa Duarte DIAS ${ }^{1}$; Renato CARRER FILHO²; Érico de Campos DIANESE³; \\ Marcos Gomes da CUNHA
}

${ }^{1}$ Doutora em Fitossanidade/Fitopatologia, Universidade Federal de Goiás, nessaduartedias@hotmail.com
${ }^{2}$ Autor para correspondência, Doutor em Fitossanidade/Fitopatologia, Núcleo de Pesquisa em Fitopatologia, Setor
Fitossanitário, Universidade Federal de Goiás, Campus Samambaia, Rod. GO-462, 74.690-900, Goiânia, GO, Brasil. Email:
carrerfilho@hotmail.com
${ }^{3}$ Ph.D. em Fitopatologia, Universidade Federal de Goiás, erico.dianese@gmail.com
${ }^{4}$ Ph.D. em Fitopatologia, Universidade Federal de Goiás, mgcunha1@gmail.com

Recebido em: 01-06-2018; Aceito em: 11-12-2018

\begin{abstract}
Leaf scald is one of the major bacterial diseases affecting sugarcane crop. Previous studies have reported the difficulty detection of the pathogen by conventional PCR when applied in asymptomatic plant material, where the pathogen population level is find below the detectable limit by conventional PCR. Because of this factor and the resilience of Xanthomonas albilineans at latent stage, our study aimed to enhance protocols, both extraction procedures of sugarcane juice and DNA extraction protocols from sugarcane juice for the detection of Xanthomonas albilineans even when the residual bacterial sample is minimal. We tested four techniques for sugarcane juice extraction: compressor, pressing, macerated and bacterial flow in water and four DNA extraction protocols, two of them considered quick or simple, a CTAB procedure and one commercial Kit. The results indicated that conventional PCR was not able to detect the pathogen in asymptomatic stalks. However, working on Nested-PCR, we could detect $X$. albilineans in latently infected plants in $100 \%$ of samples when the vascular fluid was extracted by bacterial water flow following a centrifugation, adding TAE and boiling as DNA extraction method.
\end{abstract}

Additional keywords: latency; Nested-PCR; sugarcane disease; Xanthomonas albilineans.

\section{Resumo}

A escaldadura é uma das principais doenças bacterianas que afetam a cultura da cana-de-açúcar. Estudos prévios relataram a dificuldade de detecção do patógeno pela PCR convencional quando aplicado em material vegetal assintomático, onde o nível populacional do patógeno se encontra abaixo do limite detectável pela PCR convencional. Devido a este fator e à resiliência de Xanthomonas albilineans na fase latente, o estudo deste trabalho objetivou otimizar protocolos, tanto procedimentos de extração de caldo de cana quanto protocolos de extração de DNA para a detecção de Xanthomonas albilineans. Foram testadas quatro técnicas de extração de caldo de cana: compressor, prensagem, macerado e fluxo bacteriano em água, e quatro protocolos de extração de DNA, dois deles considerados rápidos ou simples, um procedimento de CTAB e um Kit comercial. Os resultados indicaram que a PCR convencional não foi capaz de detectar o patógeno em colmos assintomáticos. No entanto, ao trabalhar com Nested-PCR, pôde-se detectar $X$. albilineans em plantas infectadas de forma latente, em $100 \%$ das amostras, quando o líquido vascular foi extraído por fluxo de água bacteriana.

Palavras-chave adicionais: doenças da cana-de-açúcar; infecção latente; Nested-PCR; Xanthomonas albilineans

\section{Introduction}

Leaf Scald (LS) is one of the major bacterial diseases affecting sugarcane crop. It is caused by Xanthomonas albilineans that multiply in a vascular bundles and can systemically colonizes the entire host plant, including leaves, stalk and roots (Klett \& Rott, 1994; Champoiseau et al., 2006; Daugross et al., 2012). The disease is characterized by chronic symptoms that start with a thin white chlorotic stripe at emerging leaves and also may extend to broad white chlorosis at extremities giving a scalded appearance to the leaf, the other common symptom in mature cane is the abnormal development of side shoots all along the stalk mainly at the bottom of the stalk (Rott \& Davis, 2000).

With disease progress the bacteria reaches the acute stage where leaf stripes and chlorosis turn into necrosis and leaves wilt and dry out. But this kind of symptoms seems to be limited to highly susceptible sugarcane cultivars (Daugross et al., 2012) and in the most cases the host not displays any symptoms (resistant or tolerant cultivars), these plants are referred as latently infected, it could be a trouble because the plants being asymptomatic carriers the bacteria in which it can be multiplying and disseminat- 
ing unnoticed around the world (Daugrois et al., 2012).

Diagnostic methods are indispensable to do an early diagnostic in asymptomatic plants, besides to test crop health, it becomes a sine qua non requirement for control efficiency and management of the disease at field, especially for seedling formation. Among the diagnostic methods common are: serological techniques, like enzyme-linked immunosorbent assay [ELISA], dot immunobinding assay [DIA], and tissue blot immunosorbent assay [TBIA]) using either monoclonal or polyclonal antisera (Comstock \& Irey, 1992), however these methods have a detection limit of a $10^{5} \mathrm{cfu} / \mathrm{ml}$ which is usually founded in symptomatic plants, therefore they are not suitable to works on asymptomatic tissues.

Molecular techniques as PCR-based (Pan et al., 1997; Pan et al., 1999; Wang et al., 1999; Jaufeerally-Fakim et al., 2002), although are considered more sensitive than serological techniques but they may also have trouble in detecting pathogens in asymptomatic tissues, mainly due to small population size and also an uneven distribution of the pathogens in situ (Garces et al., 2014).

For the real-time PCR method, although it is more sensitive than conventional PCR for specific $X$. albilineans detection (Gutierrez et al., 2016), but it requires a high investment in structure, equipment and reagents. Thus, the development of strategies for leaf scald diagnosis, especially in the case of latent infections, in a faster, sensitive and safe way is needed, it will not only help to prevent the growth of bacteria but also subsidize genetic improvement programs of sugarcane. This work aimed to optimize the molecular detection of Xanthomonas albilineans in low population densities, comparing the efficiency of sugarcane fluid extraction techniques, DNA extraction protocols to improve molecular detection by PCR and Nested-PCR.

\section{Material and methods}

\section{Plant material and sample preparation}

Nine months older symptomatic and no symptomatic stalks of the variety RB 967515 were sampled at farm in Senador Canedo, Goiás state in Brazil. Stalks were taken to the Research Sector in Phytopathology - UFG (Federal University of Goiás), washed and dried with absorbent paper, three stalk of each symptomatic and asymptomatic plant were separated and cut off in sets of one bud. The bottom part (lower third) was used to extract the fluid by compressor, pushing the fluid out thought positive pressure. For each stalk was taken $1 \mathrm{~mL}$ of vascular fluid into $1.5 \mathrm{~mL}$ tubes and stocked in $-20 \stackrel{\circ}{\circ}$ until further processing.

Population densities were determinate for each stalk sampled. Each outer superficies set selected was dipping in alcohol $70 \%$, and flaming and a transversal cut was taken by sterile pruning shears and each set was stamped in duplicate into Wilbrink's medium (10 g sucrose, $5 \mathrm{~g}$ bacto-peptone, $0.5 \mathrm{~g}$ K2HPO4, 3H2O, 0.25 g MgSO4, 1 liter deionized wa- ter, $15 \mathrm{~g}$ agar, $\mathrm{pH}$ 6.8-7.0) supplemented with cephalexin ( $\left.25 \mathrm{mg} \mathrm{L}^{-1}\right)$, novobiocin (30 mg/liter), and cycloheximide (50 $\mathrm{mg} \mathrm{L}^{-1}$ ) (Davis et al., 1994). A transversal stalk tissue section (approximately $6 \mathrm{~g}$ of tissue) was aseptically removed from each piece and cut into small fragments in a Petri dish containing 1 to $2 \mathrm{~mL}$ of sterile distilled water. The tissue homogenates were maintained at room temperature without agitation for 2 $\mathrm{h}$, and then transferred to $1.5 \mathrm{~mL}$ Eppendorf tubes and vortexed. A subsample of each homogenate was used to determine the number of $\mathrm{cfu} / \mathrm{ml}$ of $X$. albilineans preparing a tenfold serial dilutions of each homogenate were plated in triplicate on Wilbrink's medium. Bacterial colonies were counted after 4-5 days of incubation at $28^{\circ} \mathrm{C}$.

\section{Sugarcane fluid extraction assay}

To determine the best methodology for extracting sugarcane fluid on needed quantity and quality to bacterial detection by PCR, we tested four techniques to take fibrovascular fluid out: compressor, maceration, pressing and water flow. Air compressor was adapted a cup teats and fits a set of stalk witch the fluid goes out by positive pressure into a $1.5 \mathrm{~mL}$ Eppendorf tubes. For Maceration stalk tissue section of $1 \mathrm{~cm}$ wide was cut in little pieces added $1 \mathrm{~mL}$ of $2 \%$ CTAB buffer and macerated using a mortar and pestle. Pressing was done with a garlic squeeze for a transversal stalk tissue section of $1 \mathrm{~cm}$ wide and the water flow diffusate were done cutting a transversal stalk tissue section (approximately $6 \mathrm{~g}$ of tissue), was aseptically removed from each piece and cut into small fragments in a Petri dish containing 1 to $2 \mathrm{~mL}$ of sterile distilled water. The tissue homogenates were maintained at room temperature without agitation for $2 \mathrm{~h}$, and then transferred to $1.5 \mathrm{~mL}$ Eppendorf tubes and vortexed. For each method tested was taken sufficient fluid to fill eight Eppendorf tubes of $1.5 \mathrm{~mL}$ each allowing two replications per DNA extraction protocol.

\section{DNA Extraction assay}

Four protocols for total DNA extractions from sugarcane stem or fluid were compared by encompassing all of common buffer systems currently used. Three of them were adapted from original protocol: CTAB buffer, Lysis buffer and TAE buffer and the last one was a commercial Purelink Plant Total DNA Purification Kit (Invitrogen) following supplier instructions. The assay was done in triplicate for each juice extraction method.

The first DNA extraction method was a modification of the protocol described by Davis et al. (1998). One $\mathrm{mL}$ of each stalk homogenated fluid was transferred to a $1.5 \mathrm{ml}$ tube and centrifuged for $5 \mathrm{~min}$ at $500 \times \mathrm{g}$ (2240 rpm, Eppendorf Centrifuge model 5430). A $0.9 \mathrm{~mL}$ portion of the supernatant was transferred for another tuber and then centrifuged for $10 \mathrm{~min}$ at 16,050 x $g(12,700 \mathrm{rpm})$. The supernatant was discarded, and the pellet was suspended in $10 \mu \mathrm{L}$ of 
tris-acetate-EDTA (TAE) buffer amended with $0.4 \%$ nonfat dry milk (Carnation). Samples were incubated in a boiling water bath for $10 \mathrm{~min}$ and then in an ice/alcohol bath for $3 \mathrm{~min}$. This last step was repeated once after vortexing the samples.

The second DNA extraction protocol was a modification of the protocol described by Garces et al. (2014) and was used for the PCR assays. One mililiter of each stalk homogenate fluid was transferred to a $1.5 \mathrm{~mL}$ tube and centrifuged at $500 \times \mathrm{g}$ for $5 \mathrm{~min}$. A $0.9 \mathrm{~mL}$ portion of the supernatant was then centrifuged at $16,050 \times \mathrm{g}$ for $5 \mathrm{~min}$. The supernatant was discarded, and the pellet was suspended in $100 \mu \mathrm{L}$ of lysis solution $(50 \mathrm{mM} \mathrm{KCl}, 10 \mathrm{mM}$ Tris- $\mathrm{HCl}, 1 \%$ Tween 20 , $\mathrm{pH}$ 8.3). After vortex mixing, samples were incubated in a boiling water bath for $10 \mathrm{~min}$ and then in an ice/alcohol bath for $3 \mathrm{~min}$.

The third protocol was adapted CTAB from Doyle \& Doyle (1987): $250 \mathrm{mg}$ samples were placed in $2 \mathrm{~mL}$ microtubes added with $1000 \mu \mathrm{L}$ of $2 \% \mathrm{CTAB}$ buffer $\left\{p(C T A B)=20 \mathrm{~g} \mathrm{~L}^{-1}, c(\mathrm{NaCl})=1.4 \mathrm{~mol} \mathrm{~L}^{-1}, \mathrm{c}(\right.$ tris $)$ $=0.1 \mathrm{~mol} \mathrm{~L}^{-1}, \mathrm{c}(\mathrm{Na2EDTA})=0.02 \mathrm{~mol} \mathrm{~L}^{-1} ; \mathrm{pH} 8.0$ adjusted with $\mathrm{HCl}\}$, previously heated to $65^{\circ} \mathrm{C}$, and two glass beads were used to break the cell walls. The microtubes were agitated for 1 minute in a TissueLyser II bead mill at a maximum frequency of 30 oscillations per second. At the end of the process $20 \mu \mathrm{L}$ of proteinase $\left(20 \mathrm{mg} \mathrm{mL}^{-1}\right)$ were added and the microtubes were incubated in a water bath $\left(65^{\circ} \mathrm{C}\right)$ for one hour, with gentle agitation every ten minutes. The supernatant was transferred to a new microtube and added with $520 \mu \mathrm{L}$ of a 24:1 (v/v) CIA solution (chloroform: isoamyl alcohol), with manual inversion for 5 minutes. For DNA precipitation, the samples were centrifuged at $12,000 \mathrm{~g}$ for ten minutes and $600 \mu \mathrm{L}$ of the supernatant was transferred to nine $1.5 \mathrm{~mL}$ microtubes. Next, $300 \mu \mathrm{L}$ of ammonium acetate $(7.5 \mathrm{~mol} \mathrm{~L}-1)$ and $600 \mu \mathrm{L}$ of cold $96 \%$ isopropanol were added. After continuous, gentle manual inversion the solution was centrifuged at $12,000 \mathrm{~g}$ for 10 minutes and the supernatant was discarded. The precipitate was washed once with $500 \mu \mathrm{L}$ of $70 \%$ ethanol, centrifuged again at $12,000 \mathrm{~g}$ for ten minutes and resuspended in $50 \mu \mathrm{L}$ of TE (Tris $=10 \mathrm{mM}$; EDTA $=1 \mathrm{mM}, \mathrm{pH}$ 8.0). The microtubes were then added with $1 \mu \mathrm{L}$ of RNase $\mathrm{A}\left(10 \mathrm{mg} \mathrm{mL}^{-1}\right)$ and incubated at $37^{\circ} \mathrm{C} \pm 2{ }^{\circ} \mathrm{C}$ for thirty minutes. The DNA samples were kept in a freezer at $-20^{\circ} \mathrm{C}$ until quantification.

The fourth protocol was a commercial kit the Purelink Plant Total DNA Purification Kit (Invitrogen) following supplier instructions.

For all DNA extraction protocols, white control (extraction control) were used to demonstrate the absence of external nucleic acid contamination and positive control (susceptible standard contaminated with high population levels of $X$. albilineans) was used to show the efficiency of the PCR reaction

The same protocols were also tested in five different commercial varieties of sugarcane, randomly chosen, without symptoms, but wisely infected by $X$. albilineans. Thus, the aim was to certify that the method of DNA extraction is independent of the analyzed sugarcane variety. Samples were tested in duplicate, two stalks per variety and two distinct replicates. Thus, in this case, we had a total of 160 samples per analysis: four methodologies for extraction of sugarcane juice, four DNA extraction protocols, five varieties and two stems per variety.

\section{Polimerase Chain Reaction (PCR)}

The $10 \mu \mathrm{L}$ PCR reaction mix contained a $1 \mu \mathrm{L}$ aliquot from each DNA extract (stalk sample or pure culture of $X$. albilineans), $5 \mu \mathrm{L}$ of EmeraldAmp® GT PCR master mix, $0.2 \mu \mathrm{L}$ of each forward and reverse primer $2.5 \mu \mathrm{M}$, XaAlb2-f3 (CAC ACA CAC AAT ACA GCA TTG CGG) and XaAlb2-r3 (CCC AAC TTA CTT GAG GCT ATG G), $3.6 \mu \mathrm{L}$ of milli-Q $\mathrm{H}_{2} \mathrm{O}$. The conditions of amplification were an initial step at $94^{\circ} \mathrm{C}$ for 4 min; followed by 31 cycles of DNA denaturation at $94^{\circ} \mathrm{C}$ for $30 \mathrm{~s}$, annealing at $55^{\circ} \mathrm{C}$ for $30 \mathrm{~s}$, and polymerization at $65^{\circ} \mathrm{C}$ for $3 \mathrm{~min}$; and a final extension at $65^{\circ} \mathrm{C}$ for $3 \mathrm{~min}$. Nine out ten PCR products were subject to electrophoresis in 1.0\% agarose gel in TAE buffer, stained with GelRed® (Biotium), and viewed with a G:BOX imaging system (Syngene). Sizes of Amplified DNA fragments were estimated based on comparisons with molecular marker 100 bp DNA Ladder.

\section{Nested polymerase chain reaction (Nested PCR)}

PCR primers used in the first round of amplification were replaced by others in such a way that the DNA amplified in the conventional PCR becomes the target for the second pair of primers, increasing the sensitivity and specificity of the PCR, both primers were developed by Davis et al. (1998). The NestedPCR Mix was prepared following the same standard PCR protocol, but using nested primers: $1 \mu \mathrm{L}$ of the conventional PCR product described above, $3.6 \mu$ of ultrapure water, $5.0 \mu \mathrm{L}$ EmeraldAmp® GT PCR Master Mix and $0.2 \mu \mathrm{L}$ of each nested-primer XaAlb2f4 (CTT CTG CAG CTT GCT CGT C) and XaAlb2-r4 (GCT CAG TTA CGC TCA GCT AAT C) at concentration of $2.5 \mu \mathrm{M}$. The amplification conditions of PCR reactions were initial heating at $94^{\circ} \mathrm{C}$ for 2 minutes, 35 cycles of initial denaturation at $94^{\circ} \mathrm{C}$ for $40 \mathrm{~s}$, annealing at $54^{\circ} \mathrm{C}$ for $40 \mathrm{~s}$ and extension at $72^{\circ} \mathrm{C}$ for $45 \mathrm{~s}$; and a final extension at $72^{\circ} \mathrm{C}$ for $10 \mathrm{~min}$. Nine microliters of the PCR reaction were submitted to $1.5 \%$ agarose gel electrophoresis in TAE buffer, with an electrical voltage of 80 Volts, for $40 \mathrm{~min}$. The PCR product was visualized in UV (Loccus) and photodocumented translaminator. Sizes amplified DNA fragments were estimated based on comparisons with molecular marker 100 bp DNA Ladder. 


\section{Results and discussion}

Pathogen population densities had been determined by 10 fold serial dilution in selective culture medium (WSD) and $X$. albilineans population densities ranged between $10^{3}$ and $10^{4}$ for asymptomatic and symptomatic stalks respectively. This founded bacterial population is considered very critical population densities for molecular detection by PCR. For G. citricarpa conventional PCR was suitable for detecting DNA with $90 \%$ repeatability of detection at a concentration of $10 \mathrm{ng}$ and $70 \%$ at a minimum of $0.01 \mathrm{ng}$ according to the work of Faganello et al. (2017).

Thus, to improve $X$. albilinens detection in latent phase infection or in low bacteria densities in situ were tested four methodologies of sap extraction matching with four different DNA extraction protocols to find the best approach to maintain $X$. albilineans DNA without significant inhibitors to both conventional PCR and Nested-PCR. Besides, the relative cost, length, effort, use of toxic chemicals or organic solvents for each of four methods of DNA extraction were compared (Table 1).

Among the four DNA extraction protocols tested, Davis et al. (1998) and Garces et al. (2014) protocols yielded greater amount of total DNA, followed by modified CTAB protocol (Doyle \& Doyle, 1987) and Purelink Plant Total DNA Purification Kit Invitrogen®. These performances of the protocols are decurrently that the two first protocols kept almost all DNA at each step of the extraction procedure, they are very basic protocols using just a buffer plus centrifugation and boiling, for this reason, there are no losses in all steps.

Table 1 - Results for comparison of DNA extraction procedures.

\begin{tabular}{lllcc}
\hline Method & Duration & Cost & $\begin{array}{c}\text { Solvent } \\
\text { toxical/Chemical }\end{array}$ & Technical dificulty \\
\hline TAE buffer & $30 \mathrm{~min}$ & + & + & + \\
Lysis buffer & $30 \mathrm{~min}$ & + & ++ & + \\
CTAB buffer & 7 hours & ++ & ++++ & ++++ \\
Kit & 4 hours & +++ & ++++ & ++ \\
\hline
\end{tabular}

* For each one plus its to rank the process level.

The DNA purity was evaluated by measuring the ration of A260/A280 light absorptions that is used to evaluate the presence of proteins, RNA and other impurities on the DNA extraction. The optimal A260/A280 ratio is between 1.8 and 2.0 (Glasel \& Deusther, 1995), only CTAB protocol yielded DNA extraction in which the A260/A280 ratios that ranged within these parameters (Table 2), but did not critical factor to get DNA amplification. Since population densities were very low even for symptomatic stalk samples, the extraction protocol needs be one that maintain the maximum range of DNA total on samples instead of to try keep it clean and purified. Oliveira et al. (2014) stated that the quality of extracted DNA is important when sequencing the samples, or when a long sample storage time is required, or when constructing genomic libraries for future use. Furthermore it's common to extract DNA just boiling when the bacteria is gram-negative, Nogueira et al. (2004), did not find positive results on RAPD-PCR when extracted DNA of Gram-positive bacteria by boiling while when they did the same method for Gram-negative the results were positive in PCR. Alexopoulou et al. (2006) also get a positive PCR results doing similar boiling to detect gram-negative bacteria.

Table 2 - DNA concentration ( $\mathrm{ng} \mathrm{mL}^{-1}$ ) and DNA quality determined by ratio between $260 \mathrm{~nm}$ and $280 \mathrm{~nm}$ light beam, based on combination of DNA extraction protocols and sugarcane sap withdrawal techniques.

\begin{tabular}{|c|c|c|c|c|c|c|c|c|}
\hline \multirow{2}{*}{ Method } & \multicolumn{2}{|c|}{ Kit } & \multicolumn{2}{|c|}{ CTAB } & \multicolumn{2}{|c|}{ TAE buffer } & \multicolumn{2}{|c|}{ Lysis buffer } \\
\hline & (ng mL $L^{-1}$ ) & 260/280nm & $\left(n g \mathrm{~mL}^{-1}\right)$ & 260/280nm & $\left(n g \mathrm{~mL}^{-1}\right)$ & 260/280nm & $\left(n g \mathrm{~mL}^{-1}\right)$ & 260/280nm \\
\hline Compressor & 5.4 & 1.55 & 57 & 1.86 & 171 & 1.26 & 234 & 1.21 \\
\hline Maceration & 8.5 & 1.45 & 78 & 1.98 & 218 & 1.14 & 340 & 1.03 \\
\hline Pressing & 4.7 & 1.45 & 92 & 2.00 & 530 & 1.28 & 625 & 1.26 \\
\hline Water Flow & 3.5 & 1.48 & 26 & 1.82 & 174 & 1.27 & 216 & 1.00 \\
\hline
\end{tabular}

For all sugarcane varieties tested, no amplification by conventional PCR was visually detected in agarose gels for any combination of method of DNA extractions and sugarcane sap withdrawals, just positive controls (vascular fluid with populations above

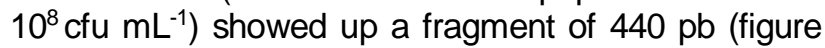

did not show). This probably occurred because the low bacterial population in situ, even for symptomatic samples (as measured by ten-fold serial dilution), the bacterial population was below $10^{4} \mathrm{cfu} \mathrm{mL}^{-1} \mathrm{PCR}$. Analogous results were achieved by Davis et al. (1998), working with bacterial population was up to $10^{3} \mathrm{cfu} \mathrm{mL}^{-1}$ 
and Wang et al. (1999), dealing with populations less than $10^{4} \mathrm{cfu} \mathrm{mL}^{-1}$ (20 cfu / PCR reaction) and Pan et al. (1999) were able to detect $X$. albilineans just in 3 out of 15 asymptomatic plants. On the other hand, Urashima and Zavaglia (2012) got 100\% detection by conventional PCR even for asymptomatic samples. In this case, they unquantified bacterial populations on their samples, however bacterial populations must be very high amount, because the sugarcane plants already showing acute phases of the sugarcane leaf scald symptoms and their samples came from only one high susceptible sugarcane variety. In our work, bacterial population densities were quantified in each stalk sampled and also we compared more than five sugarcane varieties.

A second round using Nested-PCR to detect $X$ albilineans in low population densities in at least in one of tested methodology worked very well. Bacterial DNA fragments were visualized just when was used lysis buffer as suggested by Davis et al. (1998) DNA extraction protocol (Figure 1).

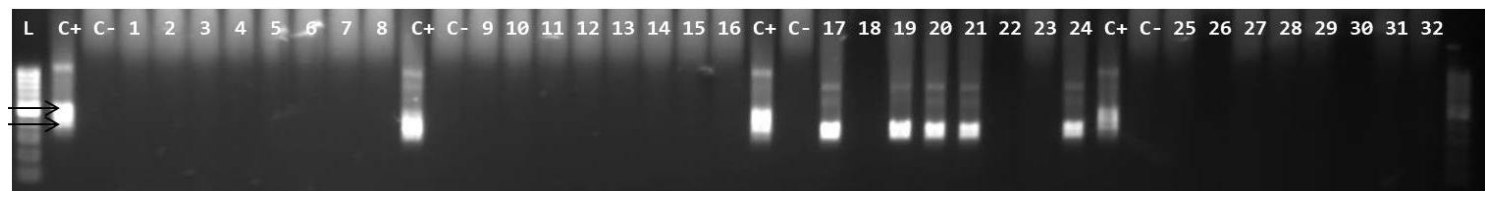

Figure 1 - Nested PCR results to detect $X$. albilineans DNA extracted from commercial Kit (1-8), CTAB 2X adapted (9-16), TAE buffer (17-24) and Lysis buffer (25-32), L: Ladder 100bp; C+: Nested positive control; C- : negative control (sugarcane healthy).

Due to promising results of the Lysis buffer protocol to extract DNA, it was tested for each one of sugarcane fluid withdrawal technique: Compressor, maceration, pressing and water flow. We attained $100 \%$ of detection of $X$. albilineans by nested-PCR when DNA was extracted from sugarcane fluid obtained by water flow approach, and $60 \%$ when sugarcane fluid was extracted by pressing (Figure 2). Nested-PCR resulted in comparable sensitivity to real-time PCR sensitivity asdescribed by Garces et al. (2014) that compared the detection of $X$. albilineans in sugarcane samples from resistant and susceptible varieties, with low disease severity since bacterial concentration was around $10^{2}$ cfu $\mathrm{mL}^{-1}$.
They ended up with $8 \%$ only of detection in their samples. In this paper when the fluid was extracted by the approach of bacterial flow in water and following the protocol Davis et al. (1998) for DNA extraction, our results were even better, detecting

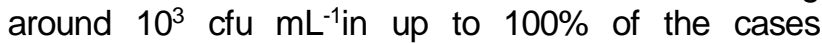
(Figure 2), only adapting the protocol of DNA extraction suggested by the same authors, with more affordable cost, laboratories not equipped with the latest generation thermocyclers required for real time PCR, this protocol can be performed in two hours compared to the 3 hours qPCR time and processes the same number of samples supported by the first .

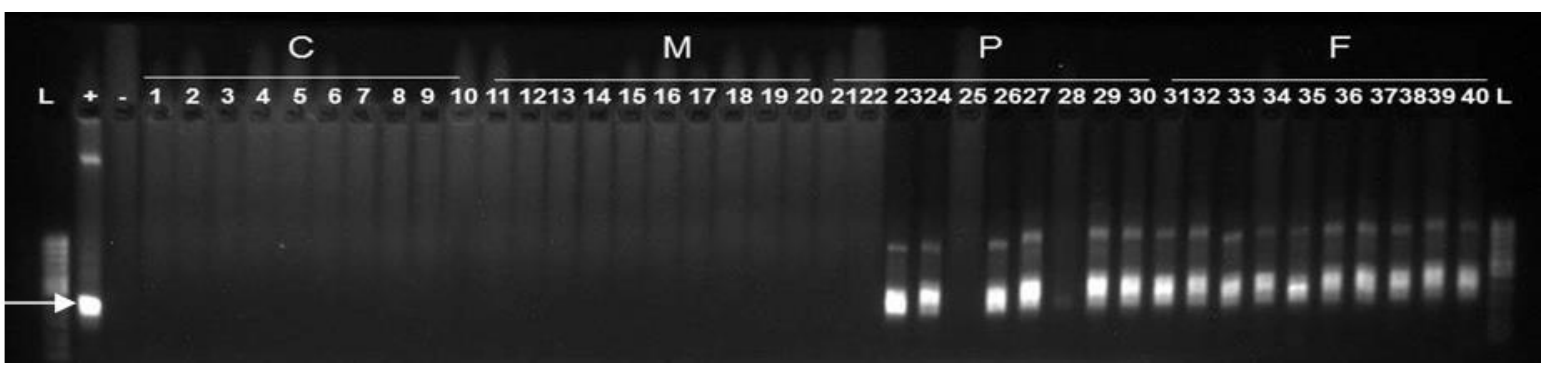

Figure 2 - Nested-PCR for DNA extracted by Davis protocol testing sap extraction by: Compressor (C)1-10, Maceration (M) 11-20, pressing (P) 21-30 and water Flow (F)31-40. L: Ladder 100bp; +: Nested positive control; - : negative control (sugarcane healthy).

Search verified by Arriola Benitez et al. (2015) detected $X$. albilineans in only one out of 35 symptomatic plants and for asymptomatic they did not get anyone DNA amplification for conventional PCR assay. Several authors have reported that this pathogen is detected more frequently in symptomatic than asymptomatic plants (Comstock \& Irey 1992, Davis et al. 1994, Pan et al. 1997, Jimenez et al. 2004).

Serological techniques like ELISA, Dot blot, tissue blot have been showed to be ineffective tools for detection of bacteria when it is in low concentrations being ineffective for detection of latent infections, as observed by Wang et al. (1999), they reached positive results just when bacteria densities were up to $10^{5} \mathrm{cfu} \mathrm{mL}^{-1}$. Another currently technique that has been showing very sensitive is real time PCR, but still considered too expensive for small detection.

As Leaf Scald in sugarcane is known as latent 
disease, it is important to use effective and sensitive detection methods to screen new propagating material. Overall, diagnostic of plant diseases had a major advance with the PCR technique from 1986 when the technique was discovered. PCR technique still is an important tool for screening pathogen in situ, the sensitivity might be improved protocol by protocol, mainly in latently cases. Therefore, Nested-PCR is efficient and applicable for the diagnosis of Leaf Scald in asymptomatic sugarcane tissues, presenting sensitivity for detection of pathogen in stalks without a visible presence of symptoms.

\section{Conclusion}

Nested-PCR is efficient and applicable for the diagnosis of Leaf Scald in asymptomatic sugarcane tissues, presenting sensitivity for detection of pathogen in stalks without a visible presence of symptoms.

\section{References}

Alexopoulou K, Foka A, Petinaki E, Jelastopulu E, Dimitracopoulos G, Spiliopoulou I (2006) Comparison of two commercial methods with PCR restriction fragment length polymorphism of the tufgene in the identification of coagulase-negative staphylococci. Letters in Applied Microbiology 43(4):450-454.

Arriola Benitez PC, Liotta DJ, Padovan C, Quiroga MI (2015) Evaluation of Two Protocols Developed for Xanthomonas albilineans Molecular Detection in Sugarcane. International Journal of Agriculture, Forestry and Fisheries 3(1):12-16.

Champoiseau P, Daugrois JH, Girard JC, Royer M, Rott PC (2006) Variation in albicidin biosynthesis genes and in pathogenicity of Xanthomonas albilineans, the sugarcane leaf scald pathogen. Phytopathology 96(1):33-45.

Comstock JC, Irey MS (1992) Detection of the leaf scald pathogen, Xanthomonas albilineans, using tissue blot immunoassay, ELISA, and isolation techniques. Plant Disease 76(2):1033-1035.

Daugrois JH, Boisne Noc R, Champoiseau P, Rott $\mathrm{P}$ (2012) The revisited infection cycle of Xanthomonas albilineans, the causal agent of leaf scald of sugarcane. Functional Plant Science Biotechnology 6(2):9197.

Davis MJ, Rott P, Baudin P, Dean JL (1994) Evaluation of selective media and immunoassay for detection of Xanthomonas albilineans, causal agent of sugarcane leaf scald disease. Plant Disease 78(1):78-82.

Davis MJ, Rott P, Astua Monge G (1998) Nested, multiplex PCR for detection of both Clavibacter xyli subsp. xyli and Xanthomonas albilineans in sugarcane. Proceedings of the Congress Plant Pathology, ISPP, Papers abstract 3 n. 3.3.4.
Doyle JJ, Doyle JL (1987) A rapid DNA isolation procedure for small quantities of fresh leaf tissue. Phytochemical Bulletin 19:11-15.

Faganello FS, Carrer Filho R, Dias VD, Morello RMSC, Cunha MG (2017) Molecular diagnosis of Guinardia citricarpa in asymptomatic sweet orange tissue. Revista Brasileira de Fruticultura 39(4):1-7.

Garces FF, Gutierrez A, Hoy J (2014) Detection and quantification of Xanthomonas albilineans by qPCR and potential characterization of sugarcane resistance to leaf scald. Plant Disease 98(1):121-126.

Glasel JA, Deutsher MP (1995) Introduction to Biophysical Methods for Protein and Nucleic Acid Research. Academic Press eBook ISBN: 9780080534985, 510p. doi.org/10.1016/B978012286230-4/50000-6.

Gutierrez A, Garces FF, Hoy JW (2016) Evaluation of resistance to leaf scald by quantitative PCR of Xanthomonas albilineans in sugarcane. Plant Disease 100(7):1331-1338.

Jaufeerally-Fakim Y, Autrey JC, Toth I, Daniels M, Dookun A (2002) Amplification polymorphism among Xanthomonas albilineans strains, using a single oligonucleotide primer. European Journal of Plant Pathology 108(2):121-130.

Jimenez O, Contreras N, Nass H (2004) Xanthomonas albilineans agente causal de la escaldadura foliar de la caña de azúcar (Saccharum sp) en los estados Lara y Yaracuy. Revista de la Facultad de Agronomia, 21(3):231-245.

Klett P, Rott P (1994) Inoculum sources for the spread of leaf scald disease of sugarcane caused by Xanthomonas albilineans in Guadeloupe. Journal of Phytopathology 142(3):283-291.

Nogueira CAM, Momesso CAS, Machado RLD, Almeida MTG, Rossit ARB (2004) Desempenho de kits comerciais e protocolos laboratoriais para a extração de DNA genômico bacteriano. Revista Panamericana de Infectologia 6(2):35-8.

Oliveira CF, Paim TGS, Reiter KC, Rieger A, D'Azevedo PA (2014) Evaluation of four different DNA extraction methods in coagulase-negative staphylococci clinical isolates. Revista do Instituto de Medicina Tropical. 56(1):29-33.

Pan YB, Grisham MP, Burner DM (1997) A polymerase chain reaction protocol for the detection of Xanthomonas albilineans, the causal agent of sugarcane leaf scald disease. Plant Disease 81(2):189-194. 
Pan YB, Grisham MP, Burner DM, Legendre BL, Wei Q (1999) Development of polymerase chain reaction primers highly specific for Xanthomonas albilineans, the causal bacterium of sugarcane leaf scald disease. Plant Disease 83(2):218-222.

Rott P, Davis MJ (Eds.) (2000) "Leaf Scald" In: "A guide to sugarcane diseases" Rott $P$, Bailey RA, Comstock JC, Croft BJ, Saumtally AS (eds.) CIRADISSCT. ISBN 2-87614386-0 p. 38-44.
Urashima AS, Zavaglia AC (2012) Comparação de dois métodos diagnósticos de escaldadura-das-folhas (Xanthomonas albilineans) da cana-de-açúcar. Summa Phytopathologica 38(2):155-158.

Wang ZK, Comstock JC, Hatziloukas E, Schaad NW (1999) Comparison of PCR, BIO-PCR, DIA, ELISA and isolation on semiselective medium for detection of Xanthomonas albilineans, the causal agent of leaf scald of sugarcane. Plant Pathology 48(2):245-252. 